\title{
Evaluation of sediment contamination by trace elements and the zooplankton community analysis in area affected by gold exploration in Southeast (SE) of the Iron Quadrangle, Alto Rio Doce, (MG) Brazil
}

\author{
Avaliação da contaminação de sedimentos por elementos traço e análise da comunidade \\ zooplanctônica em uma área afetada pela exploração aurífera histórica no Sudoeste (SE) \\ do Quadrilátero Ferrífero, Alto Rio Doce, MG, Brasil
}

Cláudia de Lima e Silva ${ }^{1}$, Adivane Terezinha da $\operatorname{Costa}^{2}$, Giovanni Guimarães Landa ${ }^{3}$,

Herton Fabrício Camargos Fonseca ${ }^{1}$ and Aléssio Silveira ${ }^{1}$

\author{
${ }^{1}$ Departamento de Engenharia Geológica, Universidade Federal de Ouro Preto - UFOP, \\ Rua Padre Faria, 60, Bairro Alto da Cruz, CEP 35400-000, Ouro Preto, MG, Brazil \\ e-mail: c_delimaesilva@yahoo.co.uk; hertonfcf@yahoo.com.br; alessiosilveira@hotmail.com \\ ${ }^{2}$ Departamento de Geologia, Escola de Minas, Universidade Federal de Ouro Preto - UFOP, \\ Morro do Cruzeiro, CEP 35400-000, Ouro Preto, MG, Brazil \\ e-mail: adivanecosta@gmail.com \\ ${ }^{3}$ Centro Universitário de Caratinga - UNEC, Campus de Nanuque, \\ Rua Nelício Cordeiro, s/n, Bairro Israel Pinheiro, CEP 39860-000, Nanuque, MG, Brazil \\ e-mail: gioguimaraes@yahoo.com.br
}

\begin{abstract}
Aim: The aim was to verify the geochemical composition of sediments samples (riverbed and bank) and the relationship of the following elements: Al, As, $\mathrm{Cd}$. $\mathrm{Cr}, \mathrm{Cu}, \mathrm{Fe}, \mathrm{Mn}, \mathrm{Ni}$ and $\mathrm{Zn}$ with the zooplankton community. Methods: Bank and riverbed sediments were collected in four sampling points along the studied area, in June/2010 (dry season) and March/2011 (rainy season). Three types of analysis were performed: granulometric, mineralogical (by X-Ray diffractometer) and geochemical (by ICPOES), where for the last two types, only a fraction of silt/clay $(<0.062 \mathrm{~mm})$ was used, and the results were compared with the following reference values: Local Reference Value (Costa et al., 2010), Quality Reference Values (São Paulo, 2005), PEC and TEC values (MacDonald et al., 2000). For identification of the zooplankton community, riverbed and bank samples were collected in polyethylene bottles, suspended with deionized water (bank sample only), stained with Rose Bengal and preserved in formalin at 4\%. Results: As concentrations at Col sampled point were 18 times greater than the Local Reference Value $\left(3.84 \mathrm{mg} \cdot \mathrm{kg}^{-1}\right)$. Cd concentrations were greater than the values established by the QRV $\left(<0.5 \mathrm{mg} \cdot \mathrm{kg}^{-1}\right)$ and PEC $\left(4.98 \mathrm{mg} \cdot \mathrm{kg}^{-1}\right)$ in almost all the sampled points, regarding seasonality. The following zooplanktonic species were identified: Arcella costata (Ehrenberg, 1847), Arcella discoides (Ehrenberg, 1843), Arcella vulgaris (Ehrenberg, 1830), Centropyxis aculeata (Ehrenberg, 1838), Centropyxis ecornis (Ehrenberg, 1841), Difflugia sp., Difflugia acuminata (Ehrenberg, 1838), Euglypha laevis (Perty, 1849), Trynema enchelys (Ehrenberg, 1938), Asplanchna priodonta (Gosse, 1850), and Bedelloida, with, approximately $81 \%$ belonging to the Protozoa group. Conclusions: The studied area, with the exception of the Tripuí point, was found to be impacted by historical gold exploration in the region, as well as by the growing urbanization. Within the elements considered to be the most toxic to the biota, As and Cd violated all their reference values. In spite of high concentrations of major and trace elements encountered at downstream points, testacea species were identified, suggesting that this group has the capacity to adapt to adverse situations.
\end{abstract}

Keywords: geochemistry, sediments, impacts, gold mining, zooplankton.

Resumo: Objetivo: o objetivo deste estudo foi verificar a composição geoquímica de amostras de sedimentos (fundo e margem) e a relação dos seguintes elementos: $\mathrm{Al}, \mathrm{As}, \mathrm{Cd}$, $\mathrm{Cr}, \mathrm{Cu}, \mathrm{Fe}, \mathrm{Mn}, \mathrm{Ni}$ e Zn, derivados da exploração aurífera que ocorreu na área de estudo, com a comunidade zooplanctônica. Métodos: Amostras de sedimento de margem e fundo foram coletadas em quatro pontos ao longo da área de estudo, nos meses de junho/2010 (seca) e março/2011 (chuva). Foram realizadas três tipos de análise: granulométrica, mineralógica por difratometria de Raios-X e geoquímica por ICPOES, sendo que para as duas últimas, foram utilizadas somente a fração silte/argila $(<0.062 \mathrm{~mm})$, e os resultados 
foram comparados com os seguintes valores de referência: Valores de Referência Local (Costa et al., 2010), Valores de Referência de Qualidade (São Paulo, 2005) e TEC e PEC (MacDonald et al., 2000). Para a identificação taxonômica da comunidade zooplanctônica, foram coletadas amostras (fundo e margem) em frascos de polietileno, suspendidas com água deionizada (margem somente), coradas com corante vital Rosa-de-Bengala, e fixadas com formalina $4 \%$. Resultados: As concentraçóes de As no ponto Col foram 18 vezes mais elevadas do que o Valor de Referência Local $\left(3.84 \mathrm{mg} \cdot \mathrm{kg}^{-1}\right)$. O cádmio apresentou concentraçóes bem acima daquelas estabelecidas pelo VRQ $\left(<0.5 \mathrm{mg} \cdot \mathrm{kg}^{-1}\right) \mathrm{e}$ PEC ( $\left.4.98 \mathrm{mg} \cdot \mathrm{kg}^{-1}\right)$ em quase todos os pontos amostrados, independente da sazonalidade. As seguintes espécies zooplanctônicas foram identificadas: Arcella costata (Ehrenberg, 1847), Arcella discoides (Ehrenberg, 1843), Arcella vulgaris (Ehrenberg, 1830), Centropyxis aculeata (Ehrenberg, 1838), Centropyxis ecornis (Ehrenberg, 1841), Difflugia sp., Difflugia acuminata (Ehrenberg, 1838), Euglypha laevis (Perty, 1849), Trynema enchelys (Ehrenberg, 1938), Asplanchna priodonta (Gosse, 1850), e Bedelloida, sendo que aproximadamente $81 \%$ pertence ao grupo Protozoa. Conclusóes: A área de estudo, com exceçáo do ponto Tripuí encontra-se impactada pela exploração histórica do ouro na região, como também, pela crescente urbanização. Dentre os elementos considerados mais tóxicos à biota, As e Cd violaram seus respectivos valores de referência (LRV, QRV, PEC e TEC) na área estudada. Apesar das altas concentraçóes de elementos maiores e traço encontradas nos pontos a jusante, espécies de testaceas foram identificadas, sugerindo que este grupo tenha uma capacidade de se adaptar à situaçôes adversas.

Palavras-chave: geoquímica, sedimentos, impactos, mineração aurífera, zooplâncton.

\section{Introduction}

Anthropic interventions in any natural system could cause impacts in the environment such as: alteration of texture of recent sedimentary deposits causing liberation of gases; availability and/or retention of nutrients and trace elements; and reduction or loss of local biodiversity (Tundisi and Tundisi, 2008). One of the primary sources of sediment contamination is the dumping of effluents, both industrial and domestic, directly into the river, without previous treatment. Runoff and underflow carrying materials, in both urban and rural areas, can also contribute increasing the concentration of some elements considered to be toxic to the environment (Canada, 1995). In the studied area, the main sources of sediment contamination are the abandoned mines and the rejects derived from the historical exploration of gold, as well as the dumping of domestic effluents into the river. Initially, the stream Ribeirão do Carmo was surface-mined for its gold found in mudslide deposits. It is an activity that persists until today in various points along the river. With the shortage of surface minerals, subterranean explorations began where gold was found embedded in quartz veins and dispersed in manganese-bearing itabirites. By the year 1817, the English Mining Company arrived in Mariana and opened the Mina de Passagem (Costa et al., 2010). This mine produced around 35 tons of gold during its active lifetime, discharging the effluents directly into Ribeirão do Carmo (Costa et al., 2010;
Borba, 2004). As this exploration went on for three centuries, it created a significant environmental impact by contaminating the surface water and sediments of the stream. Riverbed sediment is considered to be the main compartment of accumulation, availability and interaction of major and trace elements, meanwhile, the sediment on the banks is important because it represents the link between land and water environments (Cotta et al., 2006), being also the habitat for a variety of aquatic organisms (Esteves, 1988). Thus it is an important data source for assessing environmental quality, as it bears the pollution history of the area. Nowadays it is essential not only to assess the impact of pollutants in the environment, but also how the biological community reacts to this impact (Minutoli et al., 2008). Notwithstanding, the zooplankton community that resides in the sediments can be considered to be bio-indicators of a variety of types of environments, due to their small dimensions, short time interval between generations and abundance. Disturbances in the environment will reflect on these characteristics, for example, reducing the population diversity (Gagneten; Paggi, 2009). The richness may be considered similar as a biodiversity index, and can be used as a comparison, reflecting the stability of terrestrial environments that have suffered some impact and the natural ones (Li et al., 2010). 


\section{Material and Methods}

\subsection{Study area}

The studied area is located in the southwestern portion of the Iron Quadrilateral and is considered to be the Brazilian region that produced the largest amount of gold in the $18^{\text {th }}$ Century (Ladeira, 1988). The sub-basin of Ribeirâo do Carmo is located in the Piranga River Basin, which in turn, is inserted in the Unit of Planning and Management of Hydric Resources (UPGRH Doce 1), (Minas Gerais, 2010). Ribeirão do Carmo's watersheds are located in the city of Ouro Preto, being formed by the Funil and Tripuí creeks, crossing approximately East-West the city of Mariana (Figure 1). In its course, the stream flows over upper crustal rocks of the Rio das Velhas and Minas Supergroups.

\subsection{Sampling}

Four lotic points were selected for sampling (Figure 1): Tripuí (Tri) is located inside a Conservation Unit, being well preserved with the presence of riparian vegetation and endemic species of flora; Passagem (Pas), Prainha (Pra) and Colina $(\mathrm{Col})$ are located downstream the Tripuí sampling point, in densely populated urban areas, without urbanization, being garbage and domestic effluents disposed directly on the river. Sediment samples (riverbed and bank) for taxonomic identification of the zooplankton community were collected with an acrylic shovel and placed in polyethylene bottles, suspended in deionized water (bank sediment only), stained with Rose Bengal and preserved in formalin $4 \%$ (Coelho, 2004). For the species identification a binocular microscope - Bioval, model XSZ -2105BP, a Sedgewick-Rafter counting chamber, and the following taxonomic keys: Koste (1978), ElmoorLoureiro (1997), Lee et al. (1996) and Ogden and Hedley (1980) were used.

\subsection{Geochemical analysis}

Approximately five kilos of sediment (riverbed; bank) was collected, at each sampling point, with

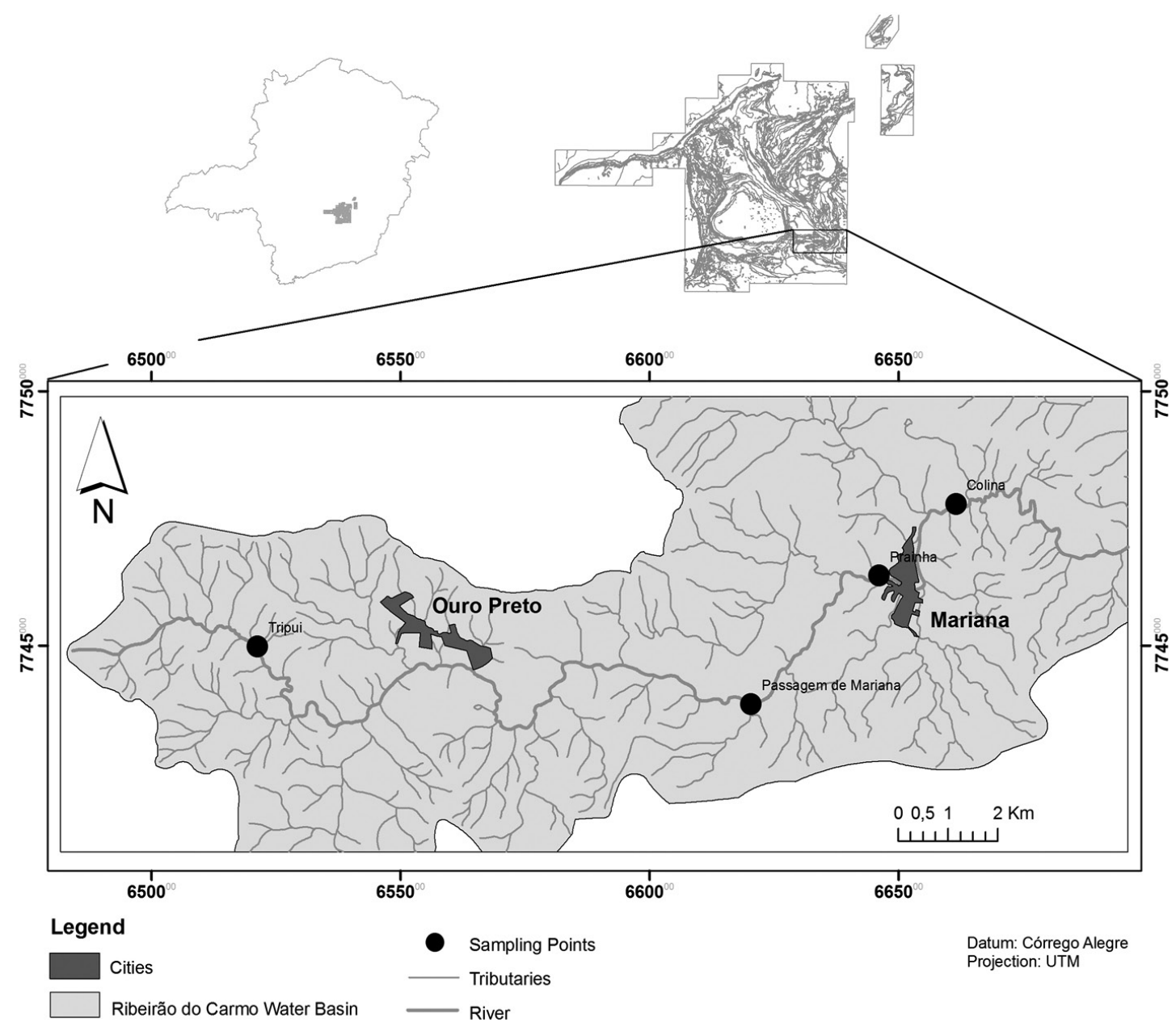

Figure 1. Study area demonstrating the sampling points. Source: modified from IBGE (2010). 
an acrylic shovel and placed in plastic bags, being naturally dried.

Geochemical characterization was complied of three types of analysis: granulometric, mineralogical by X-ray diffractometry and geochemical by ICPOES. For the last two analyses, only a silt/clay fraction $(<0.062 \mathrm{~mm})$ was used. This is due to its adsorption capacity, making it more homogeneous than another one with a larger granulometry (Deschamps et al., 2002). Analyses were performed in laboratories at the Federal University of Ouro Preto (Department of Geological Engineering) and later the results were compared to the limits established by Cetesb - Document Number 195/2005-E (São Paulo, 2005); Value Guide for Sediment Quality (TEC/PEC) by MacDonald et al. (2000) and Local Reference Values (Costa et al., 2010). A Linear Regression with the most toxic elements in the studied area (As and Cd) was developed in order to check the significance of their interaction, using Excel (Windows $7^{\mathrm{TM}}$ ).

\section{Results and Discussion}

Sampling and analyses were performed longitudinally (from upstream to downstream) beginning at the Tripuí point and ending at Colina. Regarding the granulometry of the particles, the majority of the riverbed samples $(75 \%)$ collected during the dry season was composed by Granules and the samples collected at the rainy season, by Medium Sand (75\%). The roundness of the pebbles at the sampling points where Granules predominated was considered to be very angular to angular, and their matrix is described as poorly selected. This degree of roundness and the quality of the matrix corresponds with the characterization of the sediments from headwaters, considered immature. Sediment from the bank was predominately Medium Sand (50\%) for the sampling performed in the dry season and Fine Sand $(50 \%)$ for that collected during the rainy season. The following minerals were found in the mineralogical analyses: quartz, hematite, kaolinite, gibbsite, muscovite, biotite, vermiculite, zeolite, goethite, dolomite, albite and diopside. The sediment samples from the bank collected during the dry season presented a $75 \%$ frequency of the following minerals: gibbsite, zeolite and biotite. In the riverbed samples, muscovite and zeolite were found at all sampling points and kaolinite was found in only $75 \%$ of them. For the samples collected at the rainy season, hematite, kaolinite, muscovite and albite were found in all the samples from the bank. The mineralogy of the riverbed sediment from all of the sampling points did not differ from that of the bank, being the majority of these minerals derived from the local lithology that is composed of phyllites, itabirites, schists and carbonatic rocks. It is worth mentioning that the immaturity of the sediments associated with the presence of minerals such as dolomite, albite and diopside indicates the closeness of the sediments to their source area. For comparison with reference values, the following chemical elements were selected: $\mathrm{Al}, \mathrm{As}, \mathrm{Cd}, \mathrm{Cr}$, $\mathrm{Cu}, \mathrm{Fe}, \mathrm{Mn}, \mathrm{Ni}$ and $\mathrm{Zn}$, because they represent an association with the historical contamination of the studied area (Table 1).

Arsenic, one of the principal elements derived from gold mining in the region, presented elevated values regarding the season (Figure 2 ). Its concentration increased (<Q.L. - $602 \mathrm{mg} . \mathrm{Kg}^{-1}$ ) longitudinally within the study area, with the Pra and Col points being the most contaminated.

The primary form of As occurs in arsenopyrite and pyrite minerals and is retained in superficial environments such as soil and sediments, usually through precipitation from a secondary phase, such as escorodite or goethite (Borba, 2004). The primary source of this element is intimately associated with mineralized gold sulfite derived from the abandoned mines within the studied area. In this study, the values for this element were approximately 18 times greater than the Local Reference Value (Costa et al., 2010). The origin of these high concentrations can be attributed to: weathering that occurs in the mineralized zones; erosion and dissolution of the mining waste pile; and runoff from the soil (Borba, 2004). When the water percolates through the veins present in the mineralized zone, it transports this trace element to Ribeirão do Carmo where it probably associates with or is co-precipitated by oxides and hydroxides of $\mathrm{Fe}$ and $\mathrm{Mn}$ present in the sediment (goethite

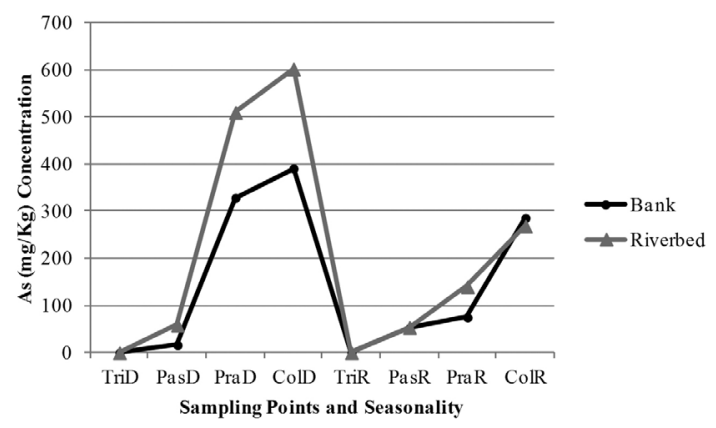

Figure 2. Longitudinal variation for $\mathrm{As}(\mathrm{mg} / \mathrm{Kg})$ concentrations. 
Table 1. Trace elements' concentration in the studied area and their respective reference values.

\begin{tabular}{|c|c|c|c|c|c|c|c|c|c|c|}
\hline Points & $\mathrm{Al}^{10}$ & As & $\mathrm{Ba}$ & Cd & $\mathrm{Cr}$ & $\mathrm{Cu}$ & $\mathrm{Fe}$ & Mn & $\mathrm{Ni}$ & $\mathrm{Zn}$ \\
\hline TriDB $^{1}$ & 3810 & $<$ Q.L. & 49.63 & $<$ Q.L. & 61.8 & 14.02 & 253448 & 2106 & 21.67 & 42.6 \\
\hline PasDB & 8534 & 16.51 & 114.1 & 1.406 & 47.67 & 21.24 & 195748 & 4499 & 22.35 & 51.8 \\
\hline PraDB & 5636 & 328.9 & 181.7 & 6.69 & 49.56 & 29.04 & 180935 & 4460 & 34.71 & 57.6 \\
\hline ColDB & 10005 & 391.3 & 247.8 & 7.65 & 81 & 32.76 & 259184 & 5802 & 39.65 & 63.8 \\
\hline TriDRB $^{2}$ & 5489 & $<$ Q.L. & 63.1 & 1.03 & 64.6 & 40.97 & 259064 & 3059 & 29.48 & 52.6 \\
\hline PasDRB & 17977 & 58.4 & 357.9 & 2.716 & 62.9 & 66.7 & 174132 & 11724 & 42.62 & 114.5 \\
\hline PraDRB & 13016 & 510 & 638 & 9.31 & 75.4 & 110.1 & 202605 & 12136 & 64.8 & 110.8 \\
\hline ColDRB & 11062 & 602 & 402.8 & 10.7 & 61.5 & 36.53 & 234214 & 6705 & 32.55 & 87.9 \\
\hline TriRB $^{3}$ & 3307 & $<$ Q.L. & 49.23 & 0.655 & 36.01 & 13.52 & 216719 & 2199 & 17.38 & 42.24 \\
\hline PasRB & 13020 & 52.5 & 71.8 & 1.494 & 76.9 & 33.61 & 158516 & 3836 & 26.45 & 52.6 \\
\hline PraRB & 5740 & 75.1 & 262.4 & 1.797 & 82.5 & 29.08 & 139811 & 4814 & 56.8 & 59.2 \\
\hline ColRB & 3636 & 286.3 & 134.6 & 4.056 & 55 & 11.26 & 236981 & 3453 & 28.01 & 45.57 \\
\hline TriRRB $^{4}$ & 3447 & $<$ Q.L. & 53.4 & 0.537 & 36.64 & 22.09 & 197371 & 2694 & 22.95 & 48.11 \\
\hline PasRRB & 9350 & 53.8 & 139.6 & 1.659 & 55.8 & 31.04 & 146815 & 6777 & 26.45 & 57.1 \\
\hline PraRRB & 3634 & 140.2 & 169 & 2.015 & 96.7 & 17.49 & 220408 & 4857 & 42.28 & 54.1 \\
\hline ColRRB & 3177 & 268.8 & 134.5 & 4.185 & 43.04 & 9.46 & 227198 & 2924 & 23.58 & 42.23 \\
\hline Q.L..$^{5}$ & 3.3 & 2.04 & 0.0491 & 0.487 & 0.271 & 0.376 & 1.06 & 0.054 & 0.751 & 0.148 \\
\hline L.R. . $^{6}$ & 3.84 & 35.3 & 18.5 & 14.06 & 111 & 135.1 & 9.88 & 189.8 & 53.1 & 124 \\
\hline Q.R. $V^{7}$ & 3.84 & 3.5 & 7.5 & $<0.5$ & 40 & 35 & 9.88 & 189.8 & 13 & 60 \\
\hline$T E C^{8}$ & N.E $E^{11}$. & 9.79 & N.E. & 0.99 & 43.4 & 31.6 & N.E. & N.E. & 22.7 & 121 \\
\hline$P E C^{9}$ & N.E. & 33 & N.E. & 4.98 & 111 & 149 & N.E. & N.E. & 48.6 & 459 \\
\hline
\end{tabular}

${ }^{1}$ Samples collected from the bank/dry season; ${ }^{2}$ Samples collected from the riverbed/dry season; ${ }^{3}$ Samples collected from the bank/rainy season; ${ }^{4}$ Samples collected from the riverbed/rainy season; ${ }^{5}$ Quantification Limit (ICPOES); ${ }^{6}$ Local Reference Value (Costa et al., 2010); ${ }^{7}$ Quality Reference Value (São Paulo, 2005); ${ }^{8}$ Threshold Effects Concentration (MacDonald et al., 2000); ${ }^{9}$ Probable Effect Concentration (MacDonald et al., 2000); ${ }^{10}$ Element concentration in mg. $\mathrm{Kg}^{-1} ;{ }^{11}$ Not Evaluated.

and hematite), as well as $\mathrm{Al}$, associated with clay minerals such as kaolinite (Costa et al., 2010). In the ore deposits of the Iron Quadrangle, manganese mainly occurs as an oxide associated with iron oxi-hydroxide very common in the rocks of the Minas and Rio das Velhas Supergroups, upstream of Ribeirão do Carmo stream (Costa et al., 2010). The As concentration at downstream (Col point) was equivalent to approximately 18 times its PEC $\left(33 \mathrm{mg} \cdot \mathrm{Kg}^{-1}\right)$. Arsenic was found in association with cadmium (Figure 3), considered one of the most toxic elements for the biota, in the studied area. The values for cadmium were also greater than those of its VRQ $\left(<0.5 \mathrm{mg} \cdot \mathrm{Kg}^{-1}\right)$ and PEC (4.98 mg. $\left.\mathrm{Kg}^{-1}\right)$ in almost all of the sampling points, regarding the season, and the higher concentrations were found at downstream points (Pra and $\mathrm{Col}$ ).

Regarding the zooplankton community, at the Pra point, the following species were identified: Difflugia sp. and Arcella vulgaris (Ehrenberg, 1830) while at the Col point: Centropyxis aculeata (Ehrenberg, 1838), Difflugia acuminata (Ehrenberg, 1838), Trynema enchelys (Ehrenberg, 1938), Asplanchna priodonta (Gosse, 1850), Bedelloida (Tables 2 and 3).
Species diversity during the dry season was higher than during the rainy season, probably indicating a seasonal pattern. Most of the species identified at the sampled points belong to the Testate amoebae group, which can be found in various environments, requiring only that they are humid (Souza, 2008). The carapace-like characteristic of this group provides resistance to environmental alterations, suggesting their dominance in this point could be related to this characteristic (Palazzo et al., 2008). In addition, Mishra et al. (1995) states that A. priodonta, Arcella sp. and Centropyxis sp. have the ability to tolerate environments with a high rate of pollution. Resting eggs identified suggest that the environment was adverse for some species of rotifers. According to Ravera (2001), when correlating the contact surface of the zooplankton organisms with their mass and metabolisms, it was verified that this combination favors a more rapid absorption of the various types of pollutants, as well as trace elements, that can be toxic to the majority of the microorganisms, depending on their concentration and exposure time (Lester, 1983). This toxicity can cause disturbances in the zooplankton community and its reflection can be noticed, for example, as 


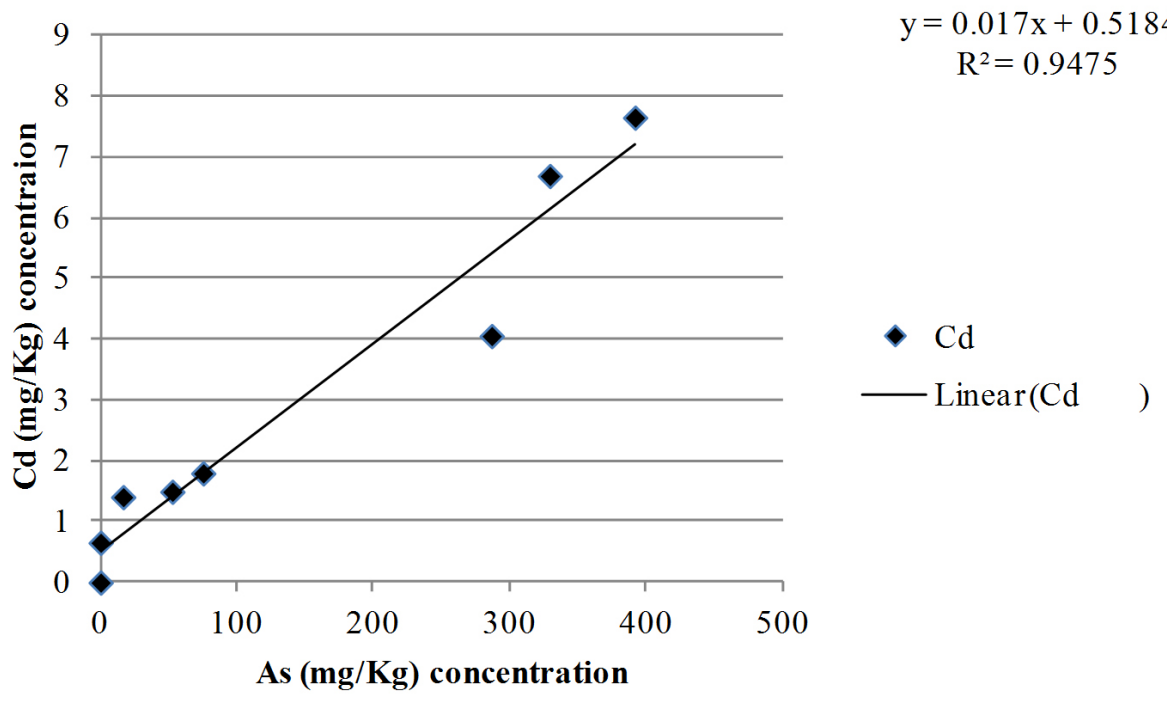

Figure 3. Linear regression for As and Cd concentrations in the studied area.

Table 2. Presence of zooplanktonic species in the sampled points for the dry season.

\begin{tabular}{lcccc}
\hline \multicolumn{1}{c}{ Organisms } & Tripuí & Colina & Passagem & Prainha \\
\hline PROTOZOA & $\mathrm{X}$ & & $\mathrm{X}$ & \\
Arcella costata & $\mathrm{X}$ & $\mathrm{X}$ & $\mathrm{X}$ & $\mathrm{X}$ \\
Arcella vulgaris & & & $\mathrm{X}$ & \\
Centropyxis aculeata & $\mathrm{X}$ & & $\mathrm{X}$ \\
Centropyxis ecornis & $\mathrm{X}$ & $\mathrm{X}$ & & \\
Difflugia sp. & & $\mathrm{X}$ & \\
Difflugia acuminata & & $\mathrm{X}$ & \\
Trinema enchelys & & $\mathrm{X}$ & & \\
ROTIFERA & & & \\
$\quad$ Asplanchna priodonta & & & \\
Bdelloida & &
\end{tabular}

Table 3. Presence of zooplanktonic species in the sampled points for the rainy season.

\begin{tabular}{lcccc}
\hline \multicolumn{1}{c}{ Organisms } & \multicolumn{3}{c}{ Rainy Season } & Prainha \\
\hline PROTOZOA & Tripuí & Colina & Passagem & \\
Arcella discoides & & & & \\
Arcella vulgaris & $\mathrm{X}$ & $\mathrm{X}$ & $\mathrm{X}$ & \\
Centropyxis aculeata & & & & \\
Euglypha laevis & $\mathrm{X}$ & & & \\
Difflugia sp. & $\mathrm{X}$ & & & \\
\hline
\end{tabular}

an alteration in the density of some species. The mechanisms through which chemical elements affect zooplankton are still not very clear, some interactions can lead to the blocking or deactivation of enzymes, disturb functions in the cytoplasm or nucleus, or even the lysis of the cell membrane. Other possible effects are: reduction in the feeding capacity and growth inhibition (Madoni, 2000).
Aquatic animals present two means of ingesting toxic substances - together with the food, or directly from the water. Hence, the concentration of a toxic element in the body of these animals is derived from various factors, such as the toxicity concentration of this element in the water, its ionic form, the type and concentration of food that was ingested. If the toxic element concentration remains stable for a period of 
time and no physiological alteration is observed in the microorganisms in question, the concentration of this toxic element will increase until it reaches a limit and from then decrease until it reaches zero, corresponding to the equilibrium between the element's concentration in the organism and its concentration in the water (Ravera, 2001). Some studies in Genetics Population indicate that after some generations, derived from parental populations that were exposed to some stress in its environment, can be developed, in this population a resistance to this stress that will be manifested phenotypically. In case the stress is removed from the environment before the development of permanent genetic tolerance, this characteristic can be reverted after some generations (EPA, 1975). According to Glime (2013), Testacea group is negatively affected by the following elements: lead $(\mathrm{Pb})$, cadmium $(\mathrm{Cd})$, zinc $(\mathrm{Zn})$ and nickel $(\mathrm{Ni})$. In spite of this, the Testacea group made up the greatest number of individuals found at the farthest downstream points, where arsenic and cadmium presented the highest concentration (Table 1). It is believed that this group has developed some form of adaptive mechanism that favors their permanence at these points. The following species were identified at Tri point: A. vulgaris, A. costata (Ehrenberg, 1847), Difflugia sp., Difflugia acuminata (Ehrenberg, 1838), e Euglypha laevis (Perty, 1849). This point, which is positioned upstream inside a Conservation Unit (Ecological Conservation Unit), was not affected by the exploration of gold and presents the lowest concentrations for the studied chemical elements. It also had the greatest diversity and could be considered to be the control point.

\section{Conclusion}

The granulometry encountered in the area suggests that Ribeirão do Carmo functions as a headwater river. The mineralogy found in the riverbed sediment matches that which was found in the bank sediment, suggesting a proximity to the area source of the sediments. Among the studied elements, As and $\mathrm{Cd}$ proved to be the most toxic for the biota, surpassing all the reference values analyzed. In spite of the high concentrations found at the downstream points (Pra and Col), zooplankton species were encountered, of which testaceas were the most abundant, suggesting that they could developed mechanisms to adapt to adverse situations. With the exception of the Tri point, it was verified that the area has been impacted by growing urbanization, historical gold mining and by independent miners who still explore the studied area, altering the geochemical composition of the sediment. Noticeable was the sorption of arsenic and cadmium by oxides and hydroxides of $\mathrm{Al}$ and $\mathrm{Mn}$, without presenting a risk to the local biota. However, these elements can suffer desorption, a process that is favored by alterations in $\mathrm{pH}$ and Eh values, making it a serious environmental threat to the studied area. The centuries of gold exploration in the area have left an environmental legacy for future generations - the contamination of the region's rivers and soil by trace elements in concentrations that could be considered toxic for the biota. It is believed that the siltation of the riverbed and the accumulation of trace elements in water and sediment of this sub-basin still affect the population and the environment. Reiterating then, the importance of the presence of $\mathrm{Al}$ and Mn oxides and hydroxides in this area because they contribute to the retention of elements like: copper, zinc, cadmium, and arsenic.

\section{References}

BORBA, RP., FIGUEIREDO, BR. and CAVALCANTI, JA. 2004. Arsênio na água subterrânea em Ouro Preto e Mariana, Quadrilátero Ferrífero (MG). Rem: Revista Escola de Minas, vol. 1, no. 57, p. 45-51. http:// dx.doi.org/10.1590/S0370-44672004000100009

Canada. 1995. Protocol for the Derivation of Canadian Sediment Quality Guidelines for the Protection of Aquatic Life. Ontario: Canadian Council of Ministers of the Environment - CCME. 47 p.

COELHO, RMP. 2004. Métodos de coleta, preservação, contagem e determinação de biomassa em zooplâncton de águas epicontinentais. In BICUDO, CEM. and BICUDO, DC., org. Amostragem em Limnologia. São Carlos: Rima. p. 149-165.

COSTA, AT., CASTRO, PT. and TATUME, SH. 2010. Análise estratigráfica e distribuição do arsênio em depósitos sedimentares quaternários da porção sudeste do Quadrilátero Ferrífero, bacia do Ribeirão do Carmo, MG. Rem: Revista Escola de Minas, vol. 4, no. 63, p. 703-714. http://dx.doi.org/10.1590/ S0370-44672010000400017

COTTA, JAO., REZENDE, MOO. and PIOVANI, MR. 2006. Avaliação do Teor de Metais em Sedimento do Rio Betari no Parque Estadual Turístico do Alto Ribeira - PETAR, São Paulo, Brasil. Quimica Nova, vol. 1, no. 29, p. 40-45. http://dx.doi.org/10.1590/ S0100-40422006000100009

DESCHAMPS, E., CIMINELLI, VST., LANGE, FT., MATSCHULLAT, J., RAUE, B. and SCHMIDT, $\mathrm{H}$. 2002. Soil and Sediment Geochemistry of the Iron Quadrangle, Brazil: The Case of Arsenic. Journal of 
Soils and Sediments, vol. 2, no. 4, p. 216-222. http:// dx.doi.org/10.1007/BF02991043

ELMOOR-LOUREIRO, LMA. 1997. Manual de Identificação de Cladóceros Límnicos do Brasil. Brasília: Universa. 156 p.

ENVIRONMENTAL PROTECTION AGENCY EPA. 1975. Freshwater Biology and Pollution Ecology. Office of Water Program Operations. 238 p.

ESTEVES, FA. 1988. Fundamentos de Limnologia. Rio de Janeiro: Interciência. 575 p.

GAGNETEN, AM. and PAGGI, JC. 2009. Effects of Heavy Metal Contamination $(\mathrm{Cr}, \mathrm{Cu}, \mathrm{Pb}, \mathrm{Cd})$ and Eutrophication on Zooplankton in the Lower Basin of the Salado River (Argentina). Water, Air, \& Soil Pollution, no. 198, p. 317-334. http://dx.doi. org/10.1007/s11270-008-9848-z

GLIME, JM. 2013. Bryological Interaction. Michigan Technological University and the International Association of Bryologists. chapter 2: Protozoa Diversity, vol. 2, 2-1-16 p.

Instituto Brasileiro de Geografia e Estatística - IBGE. 2010. Geociências - Produtos. Available from: <http:// www.ibge.gov.br/home/geociencias/default_prod. shtm>. Access in: 06 Feb 2010

KOSTE, W. 1978. Rotatoria. die radertiere mitteleuropas, Uberordnung Monogononta. Berlin: Gebruder Borntrager. 673 p.

LADEIRA, EA. 1988. Metalogenia dos depósitos de ouro do Quadrilátero Ferrífero, Minas Gerais. In SHOBBENHAUS, C. and COELHO, CE., coord. Principais Depósitos Minerais do Brasil. vol. III - Metais Básicos Não-Ferrosos, Ouro e Alumínio. Brasília: Departamento Nacional de Produção Mineral - Companhia Vale do Rio Doce. p. 301-373.

LEE, JJ., HUNTER, SH. and BOVEE, EC. 1996. An Illustrated Guide to the Protozoa. Kansas: Society of Protozoologists. 629 p.

LESTER, JN. 1983. Significance and behaviour of heavy metals in waste water treatment processes I. Sewage treatment and effluent discharges. Science of the Total Environmen, vol. 30, p. 1-44. http://dx.doi. org/10.1016/0048-9697(83)90002-5

LI, J., LI, MG., YANG, J., WANG, CF., AI, Y. and XU, RL. 2010. The community Structure of SoilSarcodina in Bayun Montain, Guangzhou, China. European Journal of Soil Biology, vol. 46, p. 1-5. http://dx.doi. org/10.1016/j.ejsobi.2009.11.001

MacDONALD, DD., INGERSOLL, CG. and BERGER, TA. 2000. Development and Evaluation of Consensus-Based Sediment Quality Guidelines for Freshwater Ecosystems. Archives of Environmental Contamination and Toxicology, vol. 39, p. 20-31. http://dx.doi.org/10.1007/s002440010075

MADONI, P. 2000. The acute toxicity of nickel to freshwater ciliates. Environmental Pollution, vol. 109, p. 53-59. http://dx.doi.org/10.1016/S02697491(99)00226-2

Minas Gerais. Secretaria Estadual de Meio Ambiente e Desenvolvimento - SEMAD. 2010. Plano Integrado de Recursos Hidricos da Bacia Hidrográfica do Rio Doce e Planos de Açóes para as Unidades de Planejamento e Gestão de Recursos Hidricos no Âmbito da Bacia do Rio Doce. Instituto Mineiro de Gestão das Águas. vol. 1, 472 p.

MINUTOLI, R., FOSSI, MC., ZAGAMI, G., GRANATA, A. and GUGLIELMO, L. 2008. First application of biomarkers approach in the zooplanktonic copepod Acartia latisetosa for the early management and conservation of transitional waters ecosystems. Transitional Waters Bulletin, vol. 1, p 45-52.

MISHRA, PC., BEHERA, N., SENAPATIAD, BK. And GURU, BC. 1995. Advances in Ecology and Environmental Sciences. New Delhi: S. B. Nangia. $628 \mathrm{p}$.

OGDEN, C.G. and HEDLEY, J.H. 1980. An Atlas of freshwater Testate Amoebae. Oxford: Oxford University Press [for the] British Museum (Natural History). $222 \mathrm{p}$.

PALAZZO, FC., BOENECKER, CC. and NAGAE, MY. 2008. Zooplankton dormancy forms in two environments of the upper Paraná River floodplain (Brazil). Acta Limnologica Brasiliensia, vol. 1, no. 20, p. 55-62.

RAVERA, O. 2001. Monitoring of the aquatic environment by species accumulator of pollutants: a review. Journal of Limnology, vol. 1, no. 60, p. 63-78.

São Paulo. 2005. Decisão de Diretoria no. 195-2005-E. Dispóe sobre a aprovação dos Valores Orientadores para Solos e Águas Subterrâneas no Estado de São Paulo, em substituiçấo aos Valores Orientadores de 2001, e dá outras providências. São Paulo: CETESB. $4 \mathrm{p}$.

SOUZA, MBG. 2008. Guia das tecamebas - Bacia do Rio Peruaçu - Minas gerais: subsídio para conservação e monitoramento da Bacia do Rio Sáo Francisco. Belo Horizonte: Editora UFMG. 159 p.

TUNDISI, JG. and TUNDISI, TM. 2008. Limnologia. São Paulo: Oficina de Textos. 631 p. 